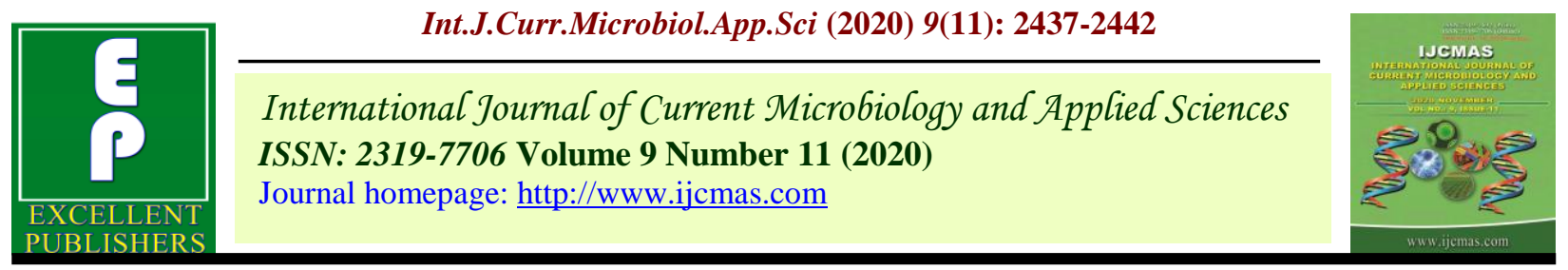

Original Research Article

https://doi.org/10.20546/ijcmas.2020.911.293

\title{
Effect of Some Plant Growth Regulators on Growth, Yield and Quality of Broccoli (Brassica oleracea L. var. italica Plenck)
}

\author{
Vandana Mandingbam ${ }^{1}$, Chadan Kumar Mandal ${ }^{2 *}$ and Sayan Jana ${ }^{2}$ \\ ${ }^{1}$ Department of Horticulture, Institute of Agricultural Science, University of Calcutta, 51/2, \\ Hazra Road, Kolkata, India \\ ${ }^{2}$ Ramkrishna Ashram Krishi Vigyan Kendra, Nimpith, Soth 24 Parganas, India \\ *Corresponding author
}

\section{A B S T R A C T}

\section{Keywords}

Broccoli, Ethrel, $\mathrm{GA}_{3}$, NAA, Lower gangetic plain

Article Info

Accepted:

17 October 2020

Available Online:

10 November 2020

\begin{abstract}
An experiment was conducted to assess exogenous application of phytohormones on growth, yield and quality of broccoli in the lower gangetic plains of West Bengal. There was ten treatment combinations i.e. control , three levels of $\mathrm{GA}_{3}(30 \mathrm{ppm}, 60 \mathrm{ppm}$ and 90 $\mathrm{ppm}$ ), three levels of NAA (40 ppm, $80 \mathrm{ppm}$ and $120 \mathrm{ppm}$ ) and three levels of Ethrel (50 ppm, $100 \mathrm{ppm}$ and $150 \mathrm{ppm}$ ) applied as aqueous spray twice at 28 and 45 days after transplanting. Data was taken on nine growth and yield related parameters (i.e. plant height $(\mathrm{cm})$, plant spread $(\mathrm{cm})$, stem diameter $(\mathrm{cm})$, number of leaves, leaf length $(\mathrm{cm})$, leaf area $(\mathrm{sqcm})$, head diameter $(\mathrm{cm})$, fresh head weight $(\mathrm{g})$, total yield $(\mathrm{Q} / \mathrm{ha})$ and three biochemical traits (i.e. total sugar content, vitamin $\mathrm{C}$ and vitamin A). Maximum value for the characters plant height $(66.55 \mathrm{~cm})$, plant spread $(85.73 \mathrm{~cm})$, head diameter $(22.77 \mathrm{~cm})$, fresh head weight $(480.43 \mathrm{~g})$, total sugar content $(5.8 \mathrm{~g} / 100 \mathrm{~g})$ and total yield $(237.25 \mathrm{q} / \mathrm{ha})$ was recorded by the treatment $120 \mathrm{ppm}$ NAA followed by $\mathrm{GA}_{3} 60 \mathrm{ppm}$ which comes out as the next equally better treatment for yield and quality improvement in broccoli.
\end{abstract}

\section{Introduction}

Morphologically, Broccoli (Brassica oleraceae L. var. italica) resembles its close relative cauliflower and belongs to the same family Brassicaceae. It possesses profuse fleshy green flower heads surrounded by leaves that brings together in a tree-like fashion on branches emerging from a thick, edible stalk. It is a cool season vegetable crop which is highly nutritious among cole vegetables. Nowadays, it draws the attention of Indian modern agriculture due to its diverse use and immense nutritional value. It provides considerable amounts of nutrients such as vitamins A (567IU), C (81.2mg) and E, magnesium, selenium which are essential for human health (Munger, 1999). Sprouting broccoli has about 130 times more vitamin A than cauliflower and 22 times more than cabbage (Singh, 2007). It is the richest source of sulforaphane (SFN) compound to the range of $214 \mu \mathrm{g}$ (stem) to $499 \mu \mathrm{g}$ (inflorescence) per gram dry weight (Olga et al., 2009), which has therapeutic potential for patients with high-risk prostate cancer (Kalia, 1995) as well 
as other cancers. An enormous research works have been reported on the uses of plant growth regulators in vegetable crops in recent years. However this kind of work is very scanty for non traditional vegetable crops like Broccoli. Various commercially exploited plant growth regulators like gibberellins $\left(\mathrm{GA}_{3}\right)$, auxin (NAA), cytokinin and ethrel have been found modifying the morphology and physiological processes that in the end affect the yield and quality of the crop.

In several cole crops, beneficial effect has been reported by earlier workers through application of $\mathrm{GA}_{3}$ and kinetin (Chhonkar and Singh, 1963; Badawi and Sahhar, 1978), although these effects are very much location specific. Hence, the present investigation was conducted to find out the best suitable plant growth regulator along with it's dose for improvement in quality and yield in broccoli in the lower gangetic plains of West Bengal.

\section{Materials and Methods}

The experiment was conducted during winter season of November, 2016 to February, 2017 at the Instructional Farm of Ramkrishna Ashram Krishi Vigyan Kendra, Nimpith, South 24 Parganas, West Bengal. This consisted of ten treatment combinations i.e. control, three levels of $\mathrm{GA}_{3}$ (30 ppm, 60 ppm, and $90 \mathrm{ppm}$ ), three levels of NAA (40 ppm, $80 \mathrm{ppm}$ and $120 \mathrm{ppm}$ ), and three levels of ethrel (50 ppm, $100 \mathrm{ppm}$ and $150 \mathrm{ppm}$ ).

Treatments were applied twice as foliar spray of synthetic plant hormones upon growing broccoli plants at 28 and 45 days after transplanting in $4 \mathrm{~m} \times 5 \mathrm{~m}$ sized plots, designed in RBD with three replications. Data was recorded from five randomly selected plants from each plots at 60 days after transplanting on nine growth and yield related parameters (i.e. plant height $(\mathrm{cm})$, plant spread $(\mathrm{cm})$, stem diameter $(\mathrm{cm})$, number of leaves, leaf length $(\mathrm{cm})$, leaf area $(\mathrm{sqcm})$, head diameter $(\mathrm{cm})$, fresh head weight $(\mathrm{g})$ and total yield $(\mathrm{q} / \mathrm{ha}))$ and three biochemical traits (i.e. total sugar content (\%), Vitamin C (mg/100g), Vitamin A (IU)). Statistical analysis was done using standard formula through Microsoft excel.

\section{Results and Discussion}

Analysis of Variance was worked out for all the twelve characters under study, which has been given in Table 1. It shows that the treatments are significantly different for all the traits, which means treatments have remarkable effect on growth, yield and quality parameters of broccoli.

Plant characters: 120 ppm of NAA recorded maximum plant height $(66.55 \mathrm{~cm})$ and plant spread $(85.73 \mathrm{~cm})$ followed by $\mathrm{GA}_{3} 90 \mathrm{ppm}$ $(65.33 \mathrm{~cm}$ and $85.27 \mathrm{~cm}$ respectively). Minimum plant height was recorded with the treatment $150 \mathrm{ppm}$ ethrel $(61.33 \mathrm{~cm})$, but in case of plant spread it was found in application of $40 \mathrm{ppm}$ NAA $(81.32 \mathrm{~cm})$ that was statistically closer to control.

The reduced plant height due to ethrel application might be its inhibitory action on auxin transport. Ethylene is an inhibitor of cell division, cell expansion and transport of auxin, which presents expressive effects on the reduction of stem growth in length; however it provides its radial expansion and horizontal orientation (Coll et al., 2001).

Maximum stem diameter was recorded with 60 ppm $\mathrm{GA}_{3}(3.54 \mathrm{~cm})$ followed by $\mathrm{GA}_{3} 90$ ppm $(3.42 \mathrm{~cm})$ and NAA 120 ppm $(3.40 \mathrm{~cm})$. Lowest value of stem diameter was recorded with control $(2.86 \mathrm{~cm})$ followed by ethrel 150 ppm $(2.88 \mathrm{~cm})$. In cabbage, Chaurasiy et al., (2014) [2] recorded highest stem diameter $(3.05 \mathrm{~cm})$ with $\mathrm{GA}_{3} 60 \mathrm{ppm}$ followed by NAA 80 ppm $(2.73 \mathrm{~cm})$ (Fig. 1 and 2; Table 2). 
Table.1 Analysis of Variance on growth, yield and quality traits of Broccoli

\begin{tabular}{|c|c|c|c|c|c|c|c|c|c|c|c|c|c|}
\hline & df & $\begin{array}{c}\text { Plant } \\
\text { height } \\
(\mathrm{cm})\end{array}$ & $\begin{array}{c}\text { Plant } \\
\text { spread } \\
\text { (cm) }\end{array}$ & $\begin{array}{c}\text { Stem } \\
\text { diameter } \\
(\mathrm{cm})\end{array}$ & $\begin{array}{c}\text { Leaf } \\
\text { length } \\
\text { (cm) }\end{array}$ & $\begin{array}{c}\text { Leaf } \\
\text { area } \\
(\mathrm{sqcm})\end{array}$ & $\begin{array}{c}\text { No. of } \\
\text { leaves } \\
\text { per plant }\end{array}$ & $\begin{array}{c}\text { Head } \\
\text { diameter } \\
(\mathrm{cm})\end{array}$ & $\begin{array}{c}\text { Fresh } \\
\text { head } \\
\text { weight } \\
\text { (g) }\end{array}$ & $\begin{array}{c}\text { Total yield } \\
\text { (Q/ha) }\end{array}$ & $\begin{array}{c}\text { Total } \\
\text { sugar } \\
\text { content } \\
\text { (g/100g) }\end{array}$ & $\begin{array}{l}\text { Vitamin C } \\
(\mathrm{mg} / \mathbf{1 0 0 g})\end{array}$ & $\begin{array}{l}\text { Vitamin A } \\
\text { (I.U/100g) }\end{array}$ \\
\hline Replication & 2 & 6.64 & 33.01 & 49.42 & 3.21 & 0.17 & 0.42 & 8.61 & 0.03 & 181.07 & 0.36 & 13.11 & 133.31 \\
\hline Treatment & 9 & $76.99 *$ & $577.98 *$ & $1838.86^{*}$ & $37.39 * *$ & $2.18 *$ & $37.81 *$ & $152.73^{*}$ & $0.28 *$ & $42729.23 *$ & $0.14 *$ & $321.65^{*}$ & $716.11 *$ \\
\hline Error & 18 & 4.99 & 32.69 & 100.65 & 1.64 & 0.13 & 1.24 & 6.46 & 0.02 & 181.07 & 0.22 & 4.91 & 71.89 \\
\hline
\end{tabular}

*Significance at 0.05

**Significance at 0.01

Table.2 Effect of plant growth hormones on growth, yield and quality traits of Broccoli

\begin{tabular}{|c|c|c|c|c|c|c|c|c|c|c|c|c|}
\hline Treatments & $\begin{array}{c}\text { Plant } \\
\text { height } \\
(\mathrm{cm})\end{array}$ & $\begin{array}{c}\text { Plant } \\
\text { spread } \\
\text { (cm) }\end{array}$ & $\begin{array}{c}\text { Stem } \\
\text { diamete } \\
\mathbf{r}(\mathrm{cm})\end{array}$ & $\begin{array}{c}\text { Leaf } \\
\text { length } \\
(\mathrm{cm})\end{array}$ & $\begin{array}{c}\text { Leaf } \\
\text { area } \\
(\mathrm{sqcm})\end{array}$ & $\begin{array}{c}\text { No. of } \\
\text { leaves } \\
\text { per } \\
\text { plant }\end{array}$ & $\begin{array}{c}\text { Head } \\
\text { diamete } \\
\mathbf{r}(\mathrm{cm})\end{array}$ & $\begin{array}{c}\text { Fresh } \\
\text { head } \\
\text { weight } \\
\text { (g) }\end{array}$ & $\begin{array}{c}\text { Total } \\
\text { yield } \\
\text { (Q/ha) }\end{array}$ & $\begin{array}{c}\text { Total } \\
\text { sugar } \\
\text { content } \\
\text { (g/100g) }\end{array}$ & $\begin{array}{l}\text { Vitamin C } \\
\text { (mg/100g) }\end{array}$ & $\begin{array}{l}\text { Vitamin A } \\
\text { (I.U/100g) }\end{array}$ \\
\hline T1 Control & 62.78 & 81.21 & 2.86 & 16.02 & 67.91 & 20.97 & 16.37 & 248.33 & 122.63 & 5.23 & 74.27 & 277.48 \\
\hline T2 GA $@ 30$ ppm & 64.67 & 83.30 & 3.28 & 18.40 & 77.20 & 23.20 & 19.33 & 338.46 & 168.14 & 4.68 & 74.40 & 279.60 \\
\hline T3 GA3@60 ppm & 64.33 & 84.22 & 3.54 & 17.43 & 75.13 & 24.30 & 22.04 & 443.33 & 217.93 & 5.31 & 75.70 & 297.90 \\
\hline T4 GA3@90 ppm & 65.33 & 85.27 & 3.42 & 17.51 & 72.36 & 23.33 & 20.51 & 414.13 & 201.44 & 5.06 & 74.24 & 293.40 \\
\hline T5 NAA@40 ppm & 63.11 & 81.32 & 3.19 & 17.96 & 74.69 & 22.07 & 20.42 & 400.66 & 198.53 & 4.92 & 73.57 & 293.17 \\
\hline T6 NAA @80 ppm & 63.77 & 82.77 & 3.31 & 17.83 & 79.53 & 21.53 & 19.39 & 393.75 & 192.44 & 4.65 & 73.87 & 293.16 \\
\hline T7 NAA@120 ppm & 66.55 & 85.73 & 3.40 & 18.12 & 77.89 & 22.97 & 22.77 & 480.43 & 237.25 & 5.80 & 75.27 & 291.30 \\
\hline T8 Ethrel @50 ppm & 63.11 & 81.53 & 3.16 & 17.78 & 73.87 & 21.30 & 19.33 & 334.09 & 167.98 & 4.97 & 72.77 & 285.93 \\
\hline T9 Ethrel @100 ppm & 61.34 & 82.33 & 3.12 & 18.09 & 74.33 & 22.40 & 18.63 & 327.78 & 160.87 & 5.13 & 71.47 & 294.88 \\
\hline $\begin{array}{l}\text { T10 Ethrel @150 } \\
\text { ppm }\end{array}$ & 61.33 & 82.52 & 2.88 & 17.54 & 72.25 & 22.77 & 17.85 & 323.08 & 159.54 & 5.44 & 68.53 & 289.25 \\
\hline SE.m $( \pm)$ & 1.29 & 1.31 & 0.21 & 0.64 & 1.79 & 0.97 & 0.47 & 9.12 & 15.89 & 0.34 & 1.62 & 4.9 \\
\hline CD (0.05) & 3.43 & 3.81 & 0.51 & 1.91 & 3.21 & 2.19 & 1.36 & 26.21 & 31.67 & 0.81 & 3.8 & 14.54 \\
\hline
\end{tabular}


Fig.1 Effect of treatment on head diameter $(\mathrm{cm})$, fresh head weight $(\mathrm{g}) \&$ total yield $(\mathrm{g})$

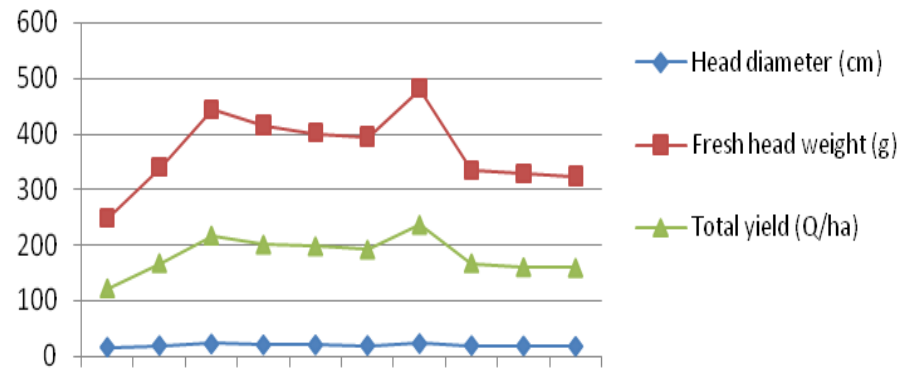

$\begin{array}{llllllllll}\text { T1 } & \text { T2 } & \text { T3 } & \text { T4 } & \text { T5 } & \text { T6 } & \text { T7 } & \text { T8 } & \text { T9 } & \text { T10 }\end{array}$

Fig.2 Effect of treatment on plant height $(\mathrm{cm})$, plant spread $(\mathrm{cm})$ and leaf area $(\mathrm{sqcm})$

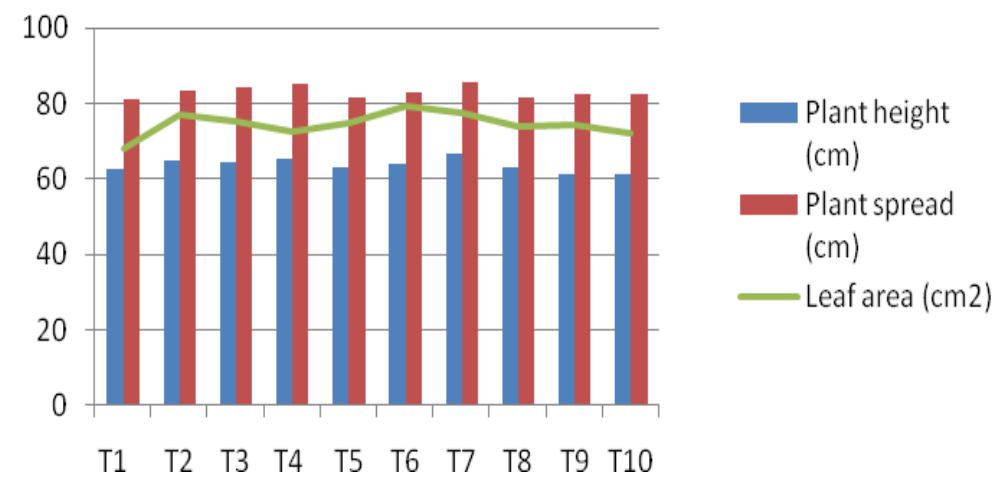

Leaf characters: In this investigation, highest leaf length was recorded with $\mathrm{GA}_{3} 30$ ppm $(18.40 \mathrm{~cm})$ followed by NAA $120 \mathrm{ppm}$ $(18.12 \mathrm{~cm})$ and ethrel $100 \mathrm{ppm}(18.09 \mathrm{~cm})$. Whereas highest leaf area was recorded with NAA $80 \mathrm{ppm}(79.53 \mathrm{sqcm})$ followed NAA $120 \mathrm{ppm}(77.89 \mathrm{sqcm})$ and $\mathrm{GA}_{3} 30 \mathrm{ppm}$ $(77.20 \mathrm{sqcm})$. Leaf area is an important character having direct effect on yield. Here, each phytohormone treatment recorded significant increase in leaf area compared to control. However, earlier findings of Mir et al., (2008) and Devi (2011) reported that foliar application of ethephon increased leaf area index in brassica and soybean. Khairul Mazed et al., (2015) observed an increase in leaf length and width with increase in $\mathrm{GA}_{3}$ concentration from 0 ppm (L- $32.36 \mathrm{~cm}$; W$26.39 \mathrm{~cm})$ to $110 \mathrm{ppm}(\mathrm{L}-34.28 \mathrm{~cm}$; W-
$28.56 \mathrm{~cm}$ ) with maximum value at $\mathrm{GA}_{3} 90$ ppm concentration (L- $36.14 \mathrm{~cm}$; W- 30.46 $\mathrm{cm})$.

Maximum number of leaves per plant was recorded with foliar application of $60 \mathrm{ppm}$ of GA3 (24.30), which is statistically at par $\mathrm{GA}_{3}$ 90 ppm (23.33), 30 ppm (23.2) \& NAA 120 ppm (22.97). Among nine treatments, minimum number of leaves was recorded with 50 ppm Ethrel (21.33) followed by NAA $80 \mathrm{ppm}$ (21.53). Singh et al., (2011) observed that $\mathrm{GA}_{3} 30 \mathrm{ppm}$ in combination with kinetin $30 \mathrm{ppm}$ recorded 16.00 number of leaves per plant in broccoli.

Head characters and yield: Maximum head diameter $(22.77 \mathrm{~cm})$ was recorded with 120 ppm NAA followed by $\mathrm{GA}_{3} 60$ ppm (22.04 
$\mathrm{cm})$, both were statistically at par to each other. Khairul Mazed et al., (2015) recorded maximum value for head diameter $(12.90 \mathrm{~cm})$ in cabbage by application of 90 ppm $\mathrm{GA}_{3}$.

Significantly highest value for fresh head weight and total yield was recorded with NAA $120 \mathrm{ppm}$ (480.43 g and $237.25 \mathrm{q} / \mathrm{ha}$ respectively) followed by $\mathrm{GA}_{3} 60 \mathrm{ppm}$ (443.33 g and $217.93 \mathrm{q} / \mathrm{ha}$ respectively). Superior and statistically at par value for these two traits were recorded by $\mathrm{GA}_{3} 90 \mathrm{ppm}$ (414.13 $\mathrm{g}$ and $201.44 \mathrm{q} /$ ha respectively), NAA $40 \mathrm{ppm}$ (400.66 g and $198.53 \mathrm{q} / \mathrm{ha}$ respectively) and NAA $80 \mathrm{ppm}(393.75 \mathrm{~g}$ and 192.44 q/ha respectively). In cabbage, similar findings have been observed by Chaurasiy et al., (2014). They recorded highest head weight $(1.73 \mathrm{~kg})$, head diameter $(18.88 \mathrm{~cm})$ and yield per hectare (51.26 t/ha) with treatment of $\mathrm{GA}_{3} 60 \mathrm{ppm}$ followed by NAA $80 \mathrm{ppm}$ and lowest in control $(0.74 \mathrm{~kg}$, $10.87 \mathrm{~cm}$ and $21.93 \mathrm{t} / \mathrm{ha}$ respectively). Similarly, Roy and Nasiruddin (2011) also recorded highest head weight $(3.55 \mathrm{~kg})$ in cabbage from 50 ppm $\mathrm{GA}_{3}$ followed by 75 ppm $\mathrm{GA}_{3}(3.43 \mathrm{~kg})$. The lowest head weight $(2.69 \mathrm{~kg})$ was recorded by the treatment control.

Biochemical characters: NAA at $120 \mathrm{ppm}$ recorded maximum total sugar content $(5.80$ $\mathrm{g} / 100 \mathrm{~g})$ followed by $150 \mathrm{ppm}$ ethrel (5.44 $\mathrm{g} / 100 \mathrm{~g})$ and $60 \mathrm{ppm} \mathrm{GA} 3(5.31 \mathrm{~g} / 100 \mathrm{~g})$. Minimum value for total sugar content was recorded with 80 ppm NAA $(4.65 \mathrm{~g} / 100 \mathrm{~g})$. In case of Vitamin $C$ content, highest value was recorded with $\mathrm{GA}_{3} 60 \mathrm{ppm}(75.70 \mathrm{mg} / 100 \mathrm{~g})$ followed by 120 ppm NAA $(75.27 \mathrm{mg} / 100 \mathrm{~g})$. Significantly least Vitamin C content was recorded with $150 \mathrm{ppm}$ ethrel (68.53 $\mathrm{mg} / 100 \mathrm{~g})$ followed by $100 \mathrm{ppm}$ ethrel (71.47 $\mathrm{mg} / 100 \mathrm{~g})$. However, all were statistically atpar with untreated control for both total sugar and vitamic $\mathrm{C}$ content.
In case of vitamin $\mathrm{A}$ content, $60 \mathrm{ppm} \mathrm{GA}_{3}$ recorded maximum value $(297.90 \mathrm{IU} / 100 \mathrm{~g})$ but was found to be at par with $100 \mathrm{ppm}$ ethrel (294.88 I.U/100g), 90 ppm GA $_{3}(293.40$ I.U/100g), 40 ppm NAA (293.17 I.U/100g), 80 ppm NAA (293.16 I.U/100g) and 120 ppm NAA (291.30 I.U/100g). Significant increase in beta carotene content in broccoli head was recorded by Singh et al., (2011) with $\mathrm{GA}_{3} 40$ ppm soaking treatment.

In conclusion the experiment has conclusively brought out some vital information on the influence of the plant growth regulators applied at 28 and 45 DAT on growth, yield and biochemical traits of broccoli. Among different treatments, foliar application of NAA 120 ppm proved best for increasing head yield and its contributing parameters as well as quality of head. However, $\mathrm{GA}_{3} 60$ ppm treatment was statistically at-par with it for most of the characters including quality and yield. So, both the PGRs can be recommended for broccoli commercial cultivation with a view to yield improvement, as well as quality enhancement.

\section{References}

Badawi MA, Sahhar EL (1978). Influence of some growth substances on different characters of cabbage. Egypt J. Hort., 6(2): 221-235.

Chaurasiy J, Meena Ml, Singh Hd, Adarsh A and Mishra Pk (2014). Effect of GA3 and NAA on Growth and Yield of Cabbage (Brassica oleracea var. capitata L.) cv. Pride of India. The Bioscan. 9(3): 1139-1141.

Chauhan UM, Tandel YN (2009). Effect of plant growth regulators on growth, yield and quality of cabbage (Brassica oleracea var capitata L.) cv. Golden Acre. Asian J. Hort., 4(2): 512-514.

Chhonkar VS, Singh R (1963). Effect of gibberellic acid on growth, yield and 
quality of cabbage (Brassica oleracea var. capitata L.). Ind. J. Hort., 21: 5763.

Coll JB, Rodrigo GN, Garcia BS and Tamés RS (2001). Etilenoy poliaminas. In: Fisiología Vegetal (Ed.: J.B. Coll, G.N. Rodrigo, B.S. Garcia and R.S. Tamés). Madrid: Ediciones Pirámide. Pp.357367.

Devi KN. (2011) Effect of bioregulators on growth, yield and chemical constituents of soybean (Glycine max). J. Agric. Sci., 3 (4):151-159.

Kalia P. (1995). Biochemical assays and yield performances of sprouting broccoli genotypes of Himachal Himalayas. Cruciferae. Newsl.; 17: 90-91.

Khairul Mazed HEM, Md. Hasanuzzaman Akand, Israt Jahan Irin, Jannatul Ferdous Moonmoon, Md. Hafizur Rahman (2015). Effect of gibberellic acid on the growth and yield of cabbage (Brassica oleracea var. capitata L.). International Journal of Applied Research. 1(4); 24-29.

Mir MR, Khan NA, Rather GH, Lonem NA and Subaya B (2008). Effect of nitrogen and ethrel on various physiological and yield attributes of mustard (Brassica juncea L.). Applied Biol. Res., 10: 1-5.

Munger HM (1979). The potential of breeding fruits and vegetables for human nutrition. Hort. Science; 14(3):247250.

Olga N Campas-Baypoli, Carolina BuenoSolano, Diana M MartínezIbarra, Francisco Camacho-Gil, Alma $\mathrm{G}$ Villa-Lerma, Jesús R RodríguezNúñez, Jaime Lóez-Cervantes, Dalia I Sánchez-Machado (2009). Sulforaphane (1-isothiocyanato-4(methylsulfinyl)-butane) content in cruciferous vegetables, Arch Latinoam Nutr.; 59(1): 95-100.

Roy R and Nasiruddin KM (2011). Effect of different level of $\mathrm{GA}_{3}$ on growth and yield of cabbage. J. Environment Science and Natural Resources. 4(2): 79-82.

Singh M, Rana DK, Rawat JMS, Rawat SS (2011). Effect of GA3 and kinetin on growth, yield and quality of sprouting broccoli (Brassica oleracea var. italica). J. Hort. \& Forestry. 3(9): 282285.

\section{How to cite this article:}

Vandana Mandingbam, Chadan Kumar Mandal and Sayan Jana. 2020. Effect of Some Plant Growth Regulators on Growth, Yield and Quality of Broccoli (Brassica oleracea L. var. italica Plenck). Int.J.Curr.Microbiol.App.Sci. 9(11): 2437-2442. doi: https://doi.org/10.20546/ijcmas.2020.911.293 